warships, M. Moritz (1500 francs), for his work on thermal motors in their relations with thermodynamics, and M. Schwartz (500 francs), for his work as a whole.

Physics.-The Hébert prize to M. Mauduit, for his treatise on electric machinery; the Hughes prize to Louis Benoist, for his researches on the X-rays; the L. La Caze prize to Jean Perrin, for his work on the kathode rays, $\mathrm{X}$-rays, and Brownian motion; the Victor Raulin prize to Mme. Marchand.

Chemistry.-The Jecker prize to Marcel Delépine, for his work in organic, inorganic, and general chemistry; the Cahours prize to MM. André Meyer and Vavon (in equal parts); the Montyon prize (unhealthy trades) is not awarded; the La Caze prize to $M$. Debierne, for his researches on the radio-active elements.

Mineralogy and Geology.-The Fontannes prize to Jean Boussac, for his memoir on the evolution of the Cerithider in the mesonummulitic of the Paris basin.

Botany.-The Desmazières prize to MM. de Istvanffi and Palinkas, for their study of the mildew of the vine, a mention being accorded to $\mathrm{M}$. Bruchmann; the Montagne prize divided between $M$. Sauvageau (Iooo francs) for his monograph on the Cystoseira, and M. Coppey (50o francs), for his bryological researches; the de Coincy prize to M. Gard, for his studies on hybrids of Cistus.

Anatomy and Zoology.-The Savigny prize to J. M. R. Surcouf; the Cuvier prize to M. Bordas, for his anatomical researches; the Thore prize to J. Feytaud, for his researches on ants.

Medicine and Surgery.-Montyon prizes (500 francs each) to H. Bierry, for his works on the glycogenic function, Ch. Nicolle, L. Blaizot, and E. Conseil (jointly), for their works on the etiology and prophylaxy of recurring fever, and E. Pinoy for his researches on the pathogenic fungi. Mentions, I500 francs each, to Ed. Delorme, for his memoir on the direct surgical treatment of cardo-pericardiac symphysis, E. Maurel, for his work on alimentation and nutrition in normal and pathological states, and $P$. Chausse, for his work on tuberculosis. Citations were accorded to André Broca, for his book on infant surgery; Robert Picqué, for his practical treatise on surgical anatomy and operative medicine; M. Roussy, for his book on five original methods for measuring the surface of the skin of the human body; M. Aynaud, for various memoirs on the question of the third element of the blood; M. Brunon, for his works relating to tuberculosis; MM. Gautrelet and Laubie; and $M$. Couvelaire, for his introduction to uterine obstetrical surgery; the Barbier prize in equal parts between H. Carré, for his memoirs on contagious agalaxy of the kid and goat, and Albert Ranc, for his studies on the physiological action of light; the Bréant prize between $H$. Vincent ( 3000 francs), for his works on the typhoid bacillus and on typhoid fever, and O. Arnaud (200o francs), for his work on cholera in the Greek army during the Balkan war; the Godard prize to Antoine Lacassagne, for his studies on the action of the X-rays on the ovary; the Baron Larrey prize divided equally between Dr. Reverchon, for his medico-military studies on the second Balkan war, and $\mathrm{H}$. Billet, for his work on the treatment of skull wounds caused by small projectiles; the Bellion prize between M. Gorini (Iooo francs), for his work on vaccines, the bacteriology of milk, and pathogenic micro-organisms, and M. Marotel (400 francs), for his researches on parasitic diseases, Raoul Dupuy receiving an honourable mention for his memoir on backward children and their treatment; the Mège prize to M. Bruntz, for his researches on the excretory organs of vertebrates and invertebrates.
Physiology.-.The Montyon prize (experimental physiology) to A. Mayer and G. Schæeffer (jointly), for their work on the lipocytic coefficient; the Philipeaux prize to Pierre Girard, for his researches on electrical osmosis; the Lallemand prize between Henri Piéron and René Legendre (goo francs jointly), for their memoir on the physiological problem of sleep, and J. Mawas ( 900 francs), for the whole of his work on the anatomy and physiology of the nervous membrane of the eye in vertebrates and in man, André Barbé being accorded a mention; the Pourat prize is not awarded; the La Caze prize (physiology) to E. Gley, for the whole of his work; the Martin-Damourette prize between M. Fauré-Fremiet (10oo francs), for his memoir on the germinative cycle in Ascaris megalocephala, and A. Lanzenberg (400 francs), for his work on ammonia and urea : origin, methods of estimation.

Statistics.-The Montyon prize to René Worms, for his studies on sexuality in French births and on agricultural associations.

History of the Sciences.-The Binoux prize is not awarded.

General Prizes.-A Berthelot medal to M. Debierne; the Gegner prize (2000 francs) to J. H. Fabre; the Lannelongue prize between Mme. Cusco and Mme. Rück; the Trémont prize to Charles Frémont; the Wilde prize between Perrier de la Bathie (3000 francs), for his geological explorations in Madagascar, and M. Schulhof (2000 francs); the Lonchampt prize to M. Javillier, for his work on the biological properties of zinc salts; the Saintour prize between R. Bigeard and H. Guillemin (I50o francs jointly), for their work on fungi, and J. Révil ( $5_{500}$ francs), for his geological work; the Henri de Parville prize between M. Berget (Iooo francs), M. Houllevigue (Iooo francs), M. Joubin (1000 francs), M. Altermann (500 francs), and M. Coupin ( 500 francs); the Houllevigue prize to $M$. Vershaffel; the Caméré prize to Augustin Mesnager; the Jerome Ponti prize between Henri Bröllemann (2500 francs), for his work on the Myriapods, and M. Pelourde (Iooo francs), for his researches on plant palæontology; the Serres prize to A. Prenant, for his work in histology, cytology, and embryology; the Jean Jacques Berger prize (I5,000 francs) to the Marquis de Vogüé, for the military hospital organised by the institute; the prize founded by the Marquise de Laplace to M. Sasportès; the prize founded by Félix Rivot between MM. Sasportès, Lévy, Jeannin, and Pélissonnier; the Bordin and Henri. Becquerel prizes are not awarded, and the Gustave Roux prize is post. poned to I9I 5 .

\section{ECONOMIC GEOLOGY IN THE UNITED STATES.}

WE have received from the United States Geological Survey a number of bulletins dealing with economic geology, namely:-"Reconnaissance of Oil and Gas Fields in Wayne and McCreary Counties, Kentucky," "Oil and Gas in the Western Part of the Olympic Peninsula, Washington," "The Ore Deposits of North-Eastern Washington," "Mining Districts of the Dillon Quadrangle, Montana," "Electric Activity in Ore Deposits." "The first two of these possess merely a local interest; the same is true to a large extent of the two next on the list, though their perusal will well repay the students of mineral deposition, more especially in the case of the bulletin on the Dillon Quadrangle, which is from the pen of Mr. Alexander N. Winchell. The last pamphlet contains an interesting study of the possible modes of development of electromotive force in ore deposits and of some of its effects, amongst which latter the deposition of the precious metals in the metallic state by electrolytic

$$
\text { No. 2358, VOL. 94] }
$$


action is perhaps the most interesting. It is worth while to direct attention to a sentence in the preface by Mr. George Otis Smith :- "It should be emphasised that the results thus far obtained afford no adequate basis for any method of electric prospecting nor any promise of the development of such a method by connecting the presence of ore deposits with readily or definitely measurable electric activity." Although no very definite results are recorded in this bulletin, it contains much suggestive material, and will probably lead to a fuller investigation of the subject.

We have also received a series of pamphlets dealing with the mineral production of the United States for 1913. In order to enable this information to be issued with the least possible delay, each chapter is issued separately as soon as the necessary statistics shall have been prepared, instead of waiting as heretofore until the whole of the statistical information needed for the entire volume was available. This system not only enables the various chapters to be issued more promptly but enables a producer to whom the statistics of one or of a limited number of substances alone are of importance to concentrate his attention on these and to find what he needs in a handy little pamphlet instead of having to deal with a bulky volume. The chapters hitherto published are-

Part i., "Metals":-(1) Bauxite and aluminium; (2) chromic iron ore; (3) gold, silver, copper, and lead in South Dakota and Wyoming; (4) manganese and manganiferous ores; (5) recovery of secondary metals. Part ii., "Non-Metals":-(I) Mica; (2) fuel briquetting; (3) sand-lime brick; (4) sulphur, pyrite, and sulphuric acid; (5) mineral paints; (6) slate; (7) potash salts; (8) fuller's earth; (9) cement industry; (10) feldspar; (II) talc and soapstone; (I2) barytes; (13) silica; (15) abrasive materials; (16) phosphate rock; (19) sand and gravel.

It need scarcely be said that the high standard of accuracy, and abundance of detail, that we are accustomed to find in the statistical publications of the United States Geological Survey have been fully maintained.

\section{IRON IN ANCIENT INDIA.}

BULLETIN No I2 of the Indian Association for the Cultivation of Science contains an interesting article on iron in ancient India, by $\mathrm{Mr}$. Panchanan Neogi, professor of chemistry in the Rajshahi College, Bengal. The author discusses the question whether iron was known in the Vedic age, and advances evidence, chiefly based on the Rigveda, in favour of the view that iron was known and used between 2000 and 1000 B.c. Whether absolute reliance can be placed on this evidence, especially as to the dates, may be open to question, but the find of ancient iron weapons on a burial site in Tinnevelly proves that iron was undoubtedly known in India in very early times; while the piece of iron slag unearthed at Bodh-Gaya shows that iron smelting had been carried on in the third century B.C., and the iron clamps found in a temple on that site, to which the date 400 to 600 A.D. has been assigned, bear evidence to a considerable advance that had then been made in the working of the metal. As regards the metallurgy of the metal, wrought iron was produced, as in all countries in early times, by the direct process from ores by smelting them in small blast furnaces without the intermediate production of cast-iron. The wellknown iron pillar near the Kutub Minar, Delhi, and the rectangular iron beams of the temple at Puri, to which the dates 640 A.D. - II 74 A.D. have been ascribed, are cited as examples of the scale on which iron forgings were made and of the remarkable slill NO. 2358, VOL. 94] attained by the workers in the metal. These gigantic forgings were constructed by welding together small blooms of iron, a method which continued to be practised in China and Japan until the middle of last century. The Delhi pillar has not rusted to a marked degree, and this resistance to corrosion is ascribed by the author to the composition of the iron, which is free from manganese and sulphur, and contains a tolerably high percentage of phosphorus. The paper also includes an interesting account of the method of making wootz or Indian steel as practised in India long prior to the manufacture of crucible steel in Europe.

\section{AN ALL-METAL DIVING DRESS.}

THE Engineer for December II contains an account of an all-metal diving dress invented in the United States of America by Mr. Chester E. Macduffee. This dress is the result of about five years' experiment, and is now claimed to have reached a practical stage.

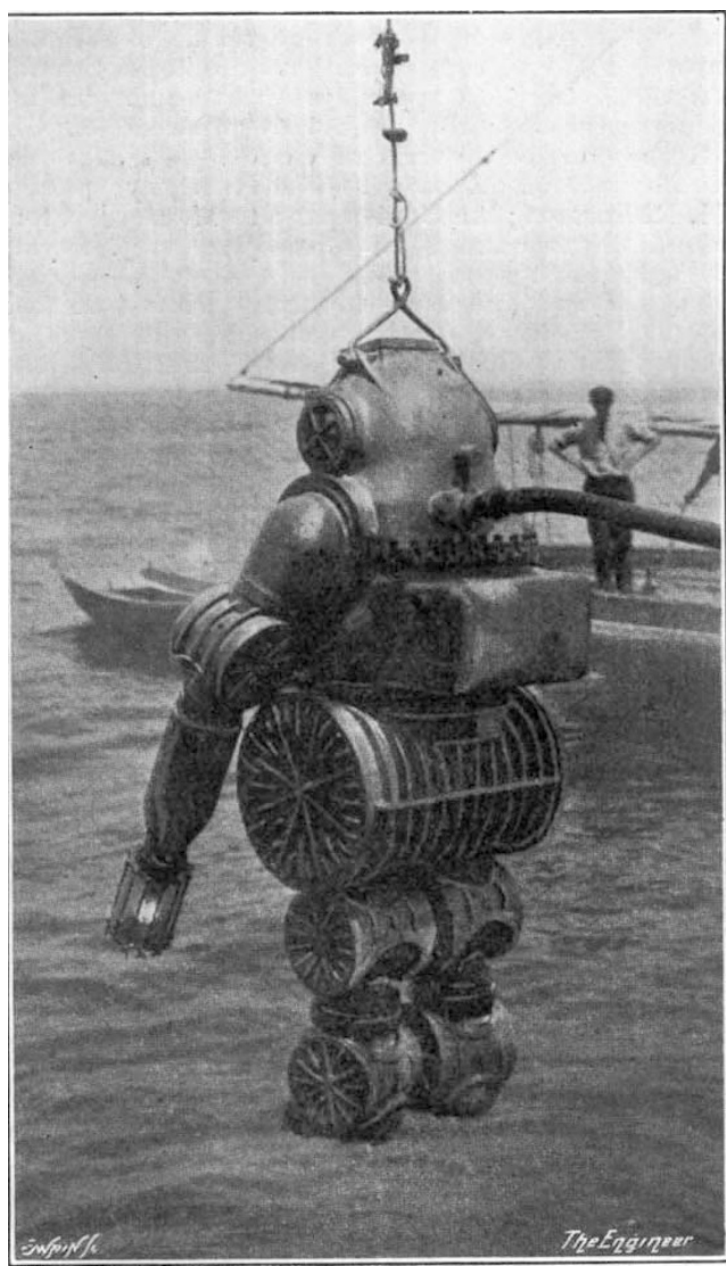

Macduffee Diving Dress. Diver coming up after submergence. s rom the Engineer.

Divers have used this armour at a maximum depth of $2 \mathrm{I} 2 \mathrm{ft}$., and could have gone deeper had more water been available. The dress is made of an aluminium alloy of great strength, and weighs empty about $480 \mathrm{lb}$.; its very considerable displacement gives it a good deal of buoyancy when in the water, and necessi- 